\title{
A Pragmatic Analysis of Hyperbole in John Keats' Love Letters to Fanny Brawn
}

\author{
Dr. Sahar Altikriti \\ Department of English, Faculty of Arts, Alzaytoonah University of Jordan, Jordan \\ P.O. Box 130, Amman, 11733, Jordan
}

Tel: 962-6-429-1511Ｅ-mail: smallcrystals@yahoo.com

Received: July 20, 2016 Accepted: August 8, 2016 Published: August x, 2016

doi:10.5296/jsel.v4i1.9885 URL: http://dx.doi.org/10.5296/jsel.v4i1.9885

\begin{abstract}
Hyperbole is an ever-present figure of speech in daily communication. It over-exaggerates the speaker's meaning through his / her intense feelings and sincere attitude towards the listener, and hence, it reflects the speaker's real intention. Hyperbole received a scant attention in comparison to other figures of speech as linguistic and discourse studies attempted to focus on the listener's response rather than considering the interactive aspect. Hyperbolic expressions have been discussed in informal everyday conversation and academic writing, but less in other genres such as the genre of love letters. Moreover, a pragmatic analysis to both notions has not been shed light upon with much consideration. Thus, the main aim of this study is to investigate both the pragmatic role of hyperbole and detect the use of politeness strategies in seven love letters written by John Keats addressed to Fanny Brawne. The analysis is based on the recognition of positive and negative politeness strategies proposed in Brown and Levinson's Theory of Politeness (1987). The study demonstrates that both positive and negative strategies and the pragmatic function of hyperbole correlate with the writer's status and vary according to the context of situation. The results of the analysis revealed that positive politeness strategies were used more frequently than negative ones. Additionally, the findings proved that Keats used hyperbole in his love letters where either positive or negative (or both) emotions revealed to make the intended message of the speaker have even more effective results on the part of the hearer with an emotive persuasion.
\end{abstract}

Keywords: Love letter, politeness strategy, Hyperbole, pragmatic functions 


\section{Introduction}

A communication situation is one in which a sender has something (a message) he / she wants (intention) to convey to a receiver. Such conveying can occur in many different ways through many different media. However, among human beings language is the most usual medium. According to Jasczolts (2002:209), communication is about intentions and inferences. Recognition of an intention may lead to its fulfillment: speaker's intentions to inform the addressee about something are fulfilled by being recognized by the addressee. Communication is successful not when the addressee recognizes the linguistic meaning of the utterance but when he/she infers the speaker's meaning from it. Austin (1962) and Searle (1979) were among the first to try to understand and categorize communication intent, form and interpretation of utterance. The mechanism according to which interlocutors recognize the intentions of the speaker is given in Grice's theory of meaning comprising the ideas of cooperation. According to Grice $(1969,1975)$, successful communication entails the exchange of communicative intentions. In this view, words do not have one-to-one relationship to the ideas a speaker is attempting to express; rather, a single utterance, such as 'It's hot in here', can convey a range of meanings and a single meaning can be expressed in a potentially infinite number of ways. In other words, as in his original formulation, Grice (1975/89 cited in Davis 1991:220) states:

[Speaker] meant something by $X$ is (roughly) equivalent to [Speaker] intend the utterance of $X$ to produce some effect in an audience by means of the recognition of this intention.

In this respect, Grice opens the way for an inferential alternative to the classical code model of communication. Consequently, the addressees must go beyond the literal meaning of a message to derive the speaker's intended meaning. Hence, intentionality represents an important factor in the discussion of interpersonal communication. This can be interpreted in terms of different persuasive strategies in language use and can be detected in cultural variation. Such variation can be reflected within the same language or between languages in terms of different persuasive strategies. Furthermore, whether within the same language or between languages, cultural differences in style have been found to reflect deep deviations within society. Thus, texts may be seen as carriers of ideological meaning, a factor that makes them particularly vulnerable to changing socio-cultural norms (Scollon and Scollon 1995). Dascal and Gross (1999) suggested to explain the relation between the communication intention and that of persuasion by presenting a combination between rhetoric and pragmatics. Although such a marriage is difficult, yet it clearly provides a theoretical choice for understanding the possibility of putting both in the same "register level of intentionality".

Letters have been identified as an area of special interest for historical pragmaticians: Letters, and in particular private letters, are a rich source of data for historical pragmatics. They contain more intimate and more colloquial language than other text types. It is an empirical question whether they are therefore closer to the spoken language than other more formal text types, but they contain many interactional features such as address terms, directives, politeness markers, apologies, and so on. Thus, the present study aims to merge the rhetorical factor of letter writing genre with relation to pragmatic parameters. 


\section{The Genre of Letters}

Writing letters is a very interesting topic. Historically, letters are among the earliest forms of writing and they represent social practices that distinguish tests, the participants, the activities and the artifacts. People's memories and traditions were preserved via songs, storytelling, ceremonies and festivals. Later on, people attempted to transfer information through marks and indents made on the stones, wood and the clay and even through knotted cords.

The text types, genres, styles and registers considered as the "terminological maze" since they are still controversial and debatable. Letters are regarded as one "text type" in contrast to others such as sermons, recipe, novel or contract. Letters may be in various types such as private / personal letters and non-private / business / official letters. However, other subtypes of letters exist such as "love letters", "requests", and "orders" (c.f. Bergs, 2004:208-209, Moessner 2001).

Letter writing is an ancient practice that goes back to the time of Sumer, ancient Egypt and ancient India, then transferred to Rome, Greece and China and eventually up to the present day. For some people, letters were only action of writing, whereas for others it was a means of communication. During certain times, such as in Byzantine, the writing of letters has risen to be a genre of literature called "epistolography". In ancient world, "epistles" were the means of communication in the form of long eloquent letters. Though epistles were more in concern with Christian life of the spirit, yet, they were patterned upon classical models. The $18^{\text {th }}$ century witnessed a flourishing of the epistolary genre across numerous settings where manuals of Letter-writing taught elite and commoner alike how to craft a wide variety of letters. According to Kenyon (1992), epistolary letter was an important root of the novel and revival models of epistles of Cicero and Horace in the eighteenth century writing letters became the center of the rhetorical theory during the Middle Ages. During that era, different letters portrayed life but the most famous sets of letters were those two passionate correspondence of Peter Abelar and his mistress, Heloise, which mirrored the poignantly, describes the currently of supposedly civilized church in twelfth century France. In the beginnings of the eleventh century, there were a whole genre of theoretical works concerned with the form and composition of the official letter, the ars dictaminis, or "art of letter writing". Some scholars have attempted to attribute the creation of this new rhetorical genre to a specific individual and to a specific place. The other letters are Paston letters which reveal the daily life of an English family in the fifteenth century. Actually, letter writing was never considered a formal subject until its inclusion as a brief appendix in the fourth century A.D. rhetoric of C. Julius Victor. Through the seventeenth and nineteenth century, a number of correspondences were used to self education, to practice critical reading, to express one's self and exchange ideas with like-minded others. In late-20th- and early-21st-century literature focused on the expansion of letter-writing cultures.

Several cross-cultural studies have focused on identifying letter writing as a significant practice where considerable communities' distinctiveness is pointed to. According to Fishman (1991), for a rural religious community in the United States, letters goes round families where each family adds a page to the bottom of the letter and removes their previous one from the 
beginning of the letter. Another study was presented by Scribner and Cole (1981) in which they found that the subject matter of Vai letter writing restricted to local news. On the other hand, in Besneir's study of Pacific islanders (1995), it was found that personal letters were widely used to express forms of affect and emotion since people avoid expressing orally.

Other studies focused on the changing contexts of letters. Kenyon studied both women's letters (1992) and the collection of intimate letters of Hamilton and Soames (1994). At the turn of the eighteenth century, the uses of letters have developed such as Tattler and The Spectator. Moreover, other works on the development of advice on how to write letters such as Steele's advice on writing love letters.

What features letters is that they are filled with specific deictic expressions as a way to refer to the writer and the intended reader and to space and time. In other words, letters are governed by two worlds: the here and now of the writer and the here and now of the reader. Interested investigators in the genre of letters made it clear that letters have a specific illocutionary force, i.e., the letter's existence has meaning as well as its content whereby reference is often made within the letter to the existence of the letter itself. The genre of the letter is more realized by functions and communication. Hence, like most other genres, letters may contain poetry and narrative. (c.f. Barton, D. and Nigel Hall, 2000: 6-7).

Great correspondences written by British writers appeared in the $19^{\text {th }}$ century. The best correspondents were John Keats (1795-1821), Lord Byron (1788-1824), Charles Dickens (1812-1870), and George Bernard Shaw (1856-1950). The letter writers, who are figures in English literature, demonstrate in their letters their literary abilities and the excellence of their style. Furthermore, letters show a more or less relaxed mood, a familiar attitude to the subject and a spirit of intimacy with the addressee. Such qualities of letters as a genre in literature qualify them as adequate representatives of the natural personality of the nation to which the letter writer belongs. Back in time and for centuries, the golden way of communication was when people were able to reveal their passionate affection to each other through love letters. Originally love letters come from necessity, from a societal disapproval, war, or some other unfortunate circumstance, two lovers could not be together. Unfortunately, love letters written by literary heroines faced a neglecting attention for some time (Kauffman, L.1986). The story of John Keats and Fanny Brawne is one such story that will be the concern of the researcher in the present study.

\subsection{Keats Love Letters to Fanny}

John Keats (31 October 1795 - 23 February 1821) was one of the pioneer English Romantic poets along with Lord Byron and Percy Bysshe Shelley and by the end of the 19th century, he had become one of the dearest of all English poets who devoted his short life to the perfection of poetry. What is found in Keats' letters signified his life and his poetical development. His works were characterized by the sensual imagery through the emphasis of natural imagery and that what makes his poems and letters very significant. During the 19th century, he was harshly criticized by the critics, but during the 20th century his works attracted their attention and highly recommended within the tenet of English literary correspondence. His most famous works were the six odes, "Hyperion" and "Endymion" as well as more than three 
dozen of affectionate letters to Fanny Brawne.

Keats met Fanny Brawne, a near neighbor in Hampstead, with whom he soon fell hopelessly and tragically in love. Frances (Fanny) Brawne Lindon (9 August $1800-4$ December 1865) is most known for her engagement to Keats a fact largely unknown until 1878 when Keats's letters were published. Keats' admiration to Fanny let him try to become closer to her by lending her books and love sonnets such as 'Bright Star' as a declaration. His jealousy for his star began to be a burden on him as darkness, depression and disease of tuberculosis surrounded him. Despite of all that, Keats sent her hundreds of notes and letters were he tried in various ways to gain her love. These letters were exchanged between them from 1818 to 1820 and considered in the present time as examples of the greatest love letters ever written. This correspondence with Fanny Brawne provides the most intimate picture of the admirable integrity of Keats's personal character and reflects the progress of his thought about his own as well as others 'poetry.

It was that time which was marked as the most poetical productive and fruitful years for Keats. Their relationship was filled with conflicted feelings, but his strong devotion and attraction was based on the feeling that she was his equal. According to White (2010: 146) the relationship between Keats and Fanny is totally different from his earlier relations to women whom he felt with less self-confidence. Being next to Fanny made him very relaxed and intimate, yet in some occasions, his actions or thoughts made him declare in letters his readiness to lose his life for her love.

In September 1820, due to his health deterioration, Keats left for Rome never seeing Fanny again and he became unable to write to her or read her letters. Five months later, he died and the news reached Fanny a month later upon which she mourned for six years.

In 1870, the publications of letters to Fanny focused on their period and emphasized the tragic aspect of his life. In the 20th century they became almost as admired and recommended to be studied in English literature. In the Twentieth Century, Wilfred Owen, W.B.Yeats and T.S. Eliot considered Keats “a key literature inspiration". T.S. Eliot's opinion about Keats sums up the brilliance of Keats as a writer and poet (c.f.: Gettings, R. 1987: 12-17):

There is hardly one statement of Keats' about poetry which ... will not be found to be true, and what is more, true for greater and more mature poetry than anything Keats ever wrote.

\section{Figurative Language and Interpersonal Rhetoric}

Writers usually use in their works several literary devices to convey their intended message in a simple way to the readers. When a writer uses literal language he/she is just reporting facts as they are, whereas in using figurative language, the writer presents a linguistic point in a more aesthetic pattern. In literature and writing, what characterizes figurative language (also called stylistic device or rhetorical device) is the use of words phrases, symbols beyond their literal meanings and ideas in a way to evoke mental images and sense impressions. Douglas (1931: 232-233) defines figurative language as "a form of expression that deviates intentionally from the ordinary mode of speech for the sake of more powerful, pleasing or distinctive effect; pictorial or poetical language". This definition revealed three aspects: (a) 
deviation from the ordinary mode of speech; (b) deviation is characterized by intentionality; and (c) a required definitive aim or purpose.

Another term used for figurative language is a traditional term called "trope" (Greek "turn") which refers to language used in a figurative pattern for a rhetorical purpose. It has several types including irony, hyperbole, metaphor, allegory, litotes, pun, personification, simile, metonymy, etc. In classical rhetoric, tropes and schemes fall under the condition of style by which they add spice to writing and speaking and they eventually associated with the production of persuasive speech, and later with aesthetics and literature (Thornborrow and Wareing1998:95).

Since emphasis, freshness of expression, or clarity are features provided by Literary devices, the present study sheds light on one of the influential stylistic devices namely 'Hyperbole'.

\subsection{Hyperbole: The Trope}

Figurative language traditionally referred to language which is different from everyday language, i.e., "nonliterary" usage. Figures were seen as a stylistic and literary framework which writers use to embellish the "ordinary" language and hence to add a persuasive taste to it (Perrine, 1979, Gibble 2005). However, researchers were more concerned with metaphor which, as Aristotle believes, represents the paradigm trope including simile, metonymy, personification and hyperbole (Rhetoric 3: 10- 11, Poetics 20-22; quoted in Dascal and Gross, 1999: 122). For Kreuz et al. (1996), the most common trope used by writers, after metaphor, is the trope of "hyperbole". In fact naming this strategy by its classical name, "hyperbole", brings to mind their role in traditional rhetoric and, hence, commemorates the continuity between "modern rhetoric" and "rhetoric" as it has been variously understood since the times of Aristotle.

Since the ancient Greek (i.e., the time of Socrates and Aristotle), "hyperbole" was realized as a rhetorical figure in written texts. The name hyperbole (hy-PER-bol- lee) is from the Greek word "hyperballein", i.e, to exceed, hit beyond the mark, from "hyper" overt "ballein" to throw, cast. In English, the word "hyperbole" is identified as:

Extravagant exaggeration by which something is represented as much greater or less, better or worse, or as involving a greater, intensity than in reality, or beyond possibility; a statement exaggerated fancifully through excitement, or for effect.

\section{(2OED,s.v. hyperbole)}

Hyperbole is one of the most widely used figures of speech or as traditionally called a "trope" not only in literature, but also in everyday language. It is an effective communication tool that is used to catch the attention, to emphasize a contrast or even to deceive of idea of the readers. It represents a reflection of a deliberate exaggeration to heighten an effect along with metaphor and simile and used for emphasis and not to be taken literally, for example Hurry we are hours late (c.f. Cano Mora 2004).

In literature, there is always that confusion on terminology between the two notions "hyperbole" and "overstatement. Overstatement is defined in (2OED, s.v. overstate): "the 
action or act of overstating, a statement which exceeds the limits of facts; exaggeration". Nonetheless, overstatement is the superordinate term which encompasses hyperbole and other notions such as excess, amplification and super fluently (c.f. Norrick, 2004; Burton, 2003, Mora, 2003). Such distinction can be better understood as Norrick (2004:1728) clarified: "it includes any extravagant statement of amplification or attenuation used to express emotion and not to be taken literally". Gibbs (1993: 266, 1994:391) made a firm statement about the complete contrast between hyperbole and overstatement since the latter is a person's unintentional expression of a proposition. In other words, Gibbs believes that what is understood by one person as overstatement might be considered hyperbole to another. This is due to the role of context as a crucial factor in interpreting hyperbolic utterances. To Swartz (1996), hyperbole is regarded as a 'structuring' of reality where focus is on one account of reality and downplay the rival ones and hence it brings the listeners into the zone of the speaker in a powerful way (c.f. McCarthy and Carter 2004: 152). Both "qualitative" and "quantitative "characterizes hyperbole as it exaggerates quantity or quality of the object. Hyperbolic expressions can be words, phrases or clauses. Such hyperbolic linguistic expression at the level of literal meaning either makes the sentence unequivocally false (e.g., There were countless applicants for the job) or as a result of the additional emotive content, the decision to identify its truth value becomes more difficult (e.g.,Your performance was frenetic). This was clearly explained by Claridge (2011, p.12):

While hyperbole is one means of intensification in the sense of gradability, [....] it is also intensification in the emotional sense, i.e. emphasis or what Labov (1984) calls 'intensity'. Emphasis as such is not dependent on a degree scale, but generally heightens the force of the proposition and marks the intensity of speaker involvement and commitment. This means that while the speaker is certainly not bound to the literal meaning of his utterance, s/he is committed to the deeper emotional and interactional, thus social, truth of the statement.

Studies on Hyperbole varied in their goals. On the linguistic level and in cross-cultural studies, most of the empirical works on hyperbole involve comparison of frequency and use in different cultures. Spitzbardt's (1963) studies have focused on hyperbole as part of the grammatical processes of intensification. From a cognitive perspective, hyperbole has been investigated to have a better understanding to the mental processes undertaken in its comprehension. Kreuz (1994:161), studied hyperbole from the discourse angle and how it permeates human communication on different levels through the discussion of the goals of "to clarify", "to emphasize", "to provoke", "to be humorous" and "to add interest". Psycholinguistically, hyperbole was researched to see how it can be perceived as a non-literal form of language as well as how it may accomplish the pragmatic functions (c.f. Colston and Keller 1998, Colston and O’Brien 2000).

McCarthy and Carter's (2004), studied the methodological and analytic framework to analyze tropes by using a large corpus. They analyzed the use of hyperbole in everyday conversation as they selected 5-million word corpus of spoken English (CANCODE) and built a framework to describe and understand hyperbole in interaction. They discriminated between those words and expressions which occur with hyperbolic and non hyperbolic function. Another study was that based on analyzing hyperbole from a semantic perspective in order to 
devise a semasiological taxonomy which enables us to understand the nature and uses of the trope.

From the survey above, hyperbole has been investigated from different perspectives and in different genres but it is realized that less work on the interactional dimensions within the pragmatic framework has been made. Norrick (1982:169) considered the speaker's effective relationship is very vital for the correct interpretation of the hyperbolic expressions. Hence, hyperbole can be considered a pragmatic phenomenon which can be realized by any part of speech or lexicogrammatical combination since it is entirely dependent on context.

Leech (1969) calls hyperbole 'honest deceptions,' because they all give a wrong representation of a situation and at the same time some indication of the true state of affairs. In other words, he believes that truthfulness is not always a case of choosing between truth and falsehood since telling the truth is a matter of degree:

Hyperbole refers to a case where the speaker's description is stronger than is warranted by the state of affairs described, and 'litotes' refers to the converse of it.

(Ibid, 1983:146)

Leech also confirmed that hyperbole can violate the maxim of quality which generates conversational implicatures. According to Gibbs (2000), hyperbole shares with the figure of speech of irony the property that literal utterance violates the maxim of quality. Similarly pointed out that at the level of what is said, although some maxim is violated, the hearer is entitled to assume that the Co-operative Principle is realized at the level of what is implicated. Therefore, Hyperbole might be considered as an act of lying at the level of what is said but not at the level of what is implicated (c.f. Grice 1975: 52)

Moreover, hyperbole is considered a strategy of politeness in the theoretical accounts of politeness. Compared with the other theories, Brown and Levinson's theory puts much emphasis on politeness in verbal communication and hyperbole, as a figure of speech, helps to enhance politeness in daily communication. Hence, this paper attempts to employ the model of Brown and Levinson's strategies of politeness to analyze the application of hyperbolic language.

\section{The Pragmatic Function of Hyperbole}

The conception of communication leads to a rhetorical approach to pragmatics, i.e., the speaker is trying to achieve his aims within constraints imposed by principles and maxims of "good communicative behavior" and among the different strategies that characterize language than the other is hyperbole. Hyperbolic expressions used to achieve different discourse goals such as providing information about the attitude of the speaker, his / her state of mind and his / her feelings. The use of the hyperbolic expressions is a pragmatic strategy for reinforcing, strengthening and intensifying the effect. In other words, the basic pragmatic function of hyperbole is to modulate one's objective state of affairs or his / her reaction to it.

Hyperbole has also been discussed within the general framework of politeness. Brown and Levinson's (1987) theory of politeness is the best to represent. They propose one such theory 
in which they claim that politeness strategies are developed in order to save the hearer's face, which is a public self image that every person wants to claim. Their notion is primarily derived from that of Goffman's (1967:5):

The positive social value a person effectively claims for himself by the line others assume he has taken during a particular contact. Face is an image of self delineated in terms of approved social attributes - albeit an image that others may share, as when a person makes a good showing for his profession or religion by making a good showing for himself.

In other words every person has two related aspects of face, negative face: the want of a person that his action be unimpeded by others and positive face: the want that his wants be desirable to at least some others. What organizes for this face-saving approach to politeness is the principle of face-threatening acts (FTAs, henceforth), which are intrinsically face threatening to either the speaker or the addressee. For example, the addressee's positive face is threatened by criticism, complaints, insults, and the use of inappropriately familiar address terms by the speaker. The speaker's positive face is threatened by having to apologize, or to confess guilt or responsibility. Others, requests, suggestions, offers, etc., while expressing thanks or offering excuses can threaten the speaker's negative face. In performing a potential FTA, speakers attempt to use a series of strategies in order to maintain face and to reduce the possibility of face threat. This is based on three main parameters: power, distance and rating of imposition which, hence, determine the overall weightiness of the FTA, which in turn influences the choice of strategy:

$$
\mathrm{Wx}=\mathrm{D}(\mathrm{S}, \mathrm{H})+\mathrm{P}(\mathrm{H}, \mathrm{S})+\mathrm{Rx}
$$

The strategy of choice is made according to the value of Wx with the lowest value of Wx leading to direct strategy followed by positive, then negative and highest value leading to off-direct strategy (c.f. Turner 1969, Coulthard 1985, Katriel 1986).Brown and Levinson (1987: 69) posit the following taxonomy of super strategies for performing FTAs:

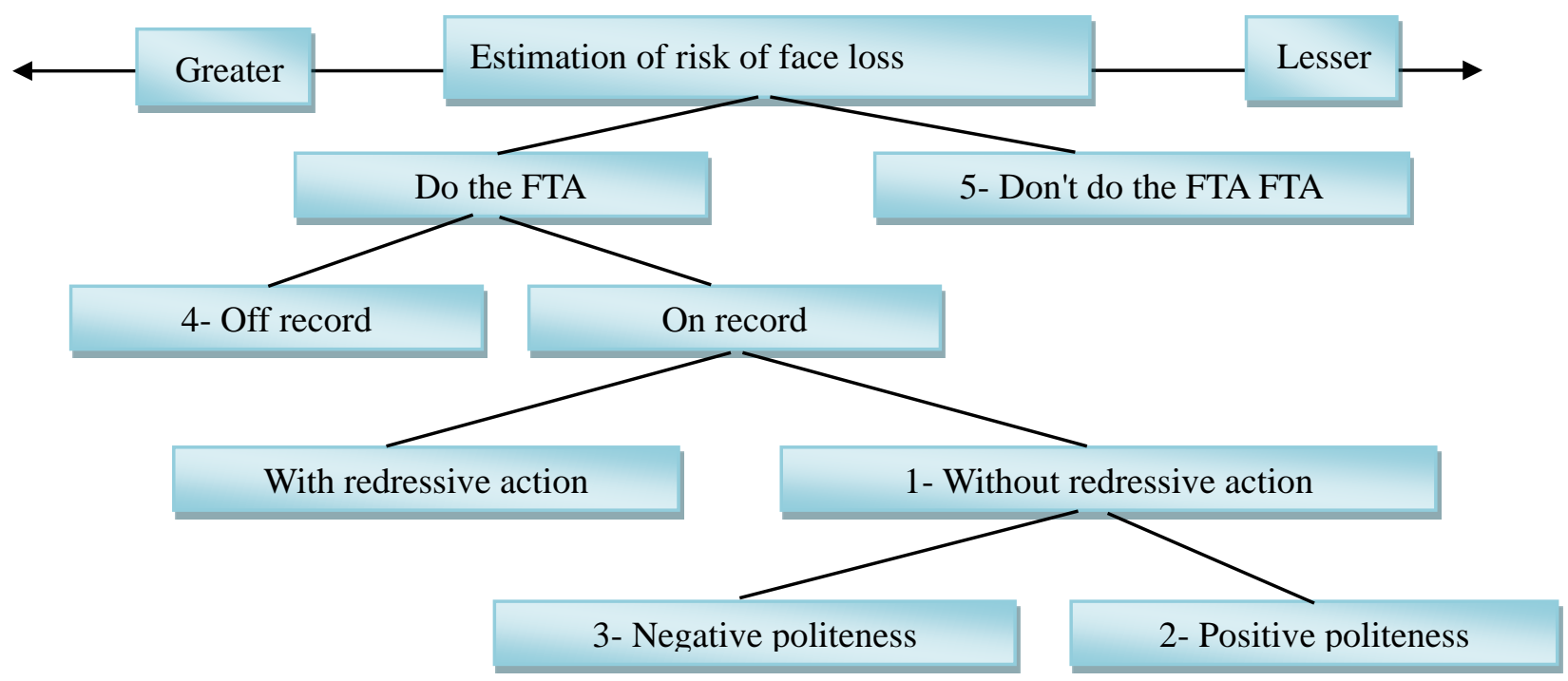

Figure 1. Strategies for doing FTAs (Brown \& Levinson 1987/2002:60, 68) 
Politeness consists of a set of strategies that serve to minimize the risks to face or self-esteem whenever a speaker commits a face-threatening act. To carry out an FTA, a speaker may select one of the four following strategies (c.f. Yaqubi, M. 2016:53-54):

(1) Bald on record (Direct) carries the speech act in a direct, clear, unambiguous and concise way, for example: "Close the door".

(2) Positive Politeness aims the positive self-image of the addressee. A speaker can employ positive politeness strategies by, among other possibilities, noticing and fulfilling the addressee's wants (e.g., giving compliments), avoiding disagreement, showing interest, offering a contribution or a benefit, being optimistic, and claiming in-group membership.

(3) Negative Politeness is used if the speaker may be imposing on the hearers, intruding on their space or violating their freedom of action, or by minimizing the imposition. These can include apologizing, expressing thanks, giving deference, being indirect, and being pessimistic.

(4) Off record (Indirect) means doing the communicative act in an indirect way, with more than an ambiguously attributable intention so that the speaker may remove himself from any imposition whatsoever; such as using metaphor and irony, rhetorical questions, hyperbole, litotes, etc.

In the comprehensive theory of politeness, Brown and Levinson (1987: 102,114) introduce hyperboles and related tropes as an extremely common politeness strategy used to perform FTAs on record with redressive action. Brown and Levinson postulated that such acts are potentially FTAs inherently damage the face of the hearer $(\mathrm{H})$ or the speaker $(\mathrm{S})$ by acting in opposition to the wants and desires of the other (c.f. Yaqubi, M. et.al, 2012:68). They point out that as a positive politeness technique, hyperbole is oriented towards the hearer's positive face, to claim common ground, conveying that some want of the hearer is also admirable or interesting to the speaker, through exaggerating interest, approval or sympathy with the hearer or as a device for intensifying interest to the hearer. In other words, If a communicative act is done off record, then it is done in such a way that it is not possible to attribute only one clear communicative intention to the act. If a speaker wants to do an FTA, but wants to avoid the responsibility for doing it, he can do it off record and leave it up to the addressee to decide how to interpret it.

The notion that politeness arises in the form of implicatures has been the interest of several scholars such as Leech (1983), Kallia's (2004) and Terkourafi's (2003). They have advocated a Politeness Principle to complement the Cooperative Principle, proposing a maxim of politeness or even arguing that politeness can arise in the form of both particularized and generalized implicatures. Additionally, Brown and Levinson's approach to the Gricean model of Cooperative Principle was based on the assumption that the addressee is able to infer the intended meaning by flouting one of the Gricean (1975) maxims. Based on this fact, hyperbole is an off-record politeness technique used to perform more concretely, by flouting Grice's maxim of quantity and so generating a conversational implicature. 


\section{Data Analysis}

The present study is concerned with the pragmatic analysis of seven love letters written by Keats to his beloved Fanny (October 1819- March 1820) which were gathered from http://englishhistory.net . The adopted model of analysis is based on the Politeness Theory of Brown and Levinson (1987). The focus of the analysis is on identifying the literary device of hyperbole in terms of the FTAs and communicative conditions. As a result of the analysis, it is realized that the positive politeness strategies accounts (109) instances higher than the negative politeness strategies (61) out of the total FTAs in the data (170). The presence of the positive strategies versus the negative ones varies in the threat posed to the hearer's or speaker's face. The analysis also revealed that the both positive and negative politeness strategies threatening the hearer's face are higher than those posed to the speaker's as shown in Table (1) below:

Table 1. Breakdown of FTAs of Hyperbole in the Data

\begin{tabular}{|l|l|l|l|}
\hline FTAs & To the Hearer & To the Speaker & Total \\
\hline Negative & 58 & 3 & 61 \\
\hline Positive & 71 & 38 & 109 \\
\hline & & 170 \\
\hline
\end{tabular}

Keats in his love letters to Fanny expressed his complaints and dissatisfaction several times of a certain act or aspect related to her. At the same time, he threatened his face for the sake of his beloved by keeping self-humiliating himself. Interestingly, the results of the analysis revealed that both FTAs of complaining (28\%) and self-humiliation (23\%) represent the highest occurrence in the data of the total (109\%) encompassing the hyperbolic function as shown in (Figure 2). This is an important marker of Keats contradictory feelings where once expresses his dissatisfaction with Fanny's actions and in other circumstances, he beseeches her love to the degree of humiliation. The following are examples of the hyperbolic complaints and self- humiliation forms found in the data:

(1) My Mind has been the most discontented and restless one that ever was put into a body too small for $i$.

(2) a Task which would worry a stout state of the body and mind, but which just suits me as I can do no more.

(3) I am tormented day and night.

(4) I have had a thousand kisses, for which with my whole soul I thank love - but if you should deny me the thousand and first - 't would put me to the proof how great a misery I could live through.

(5) I should be exquisitely miserable without the hope of soon seeing you. 


\section{Mll Macrothink}

(6) I can do that no more - the pain would be too great - My Love is selfish - I cannot Breathe without you.

(7) I am literally worn to death, which seems my only recourse.

In the examples above, Keats uses hyperbole to show how deep his love to Fanny is and at the same time how miserable he is expressing his pain for not being satisfied with his love. Once he humiliates himself and by this he projects his face to be threatened for the sake of the addressee. On the other hand he projects threats to the face of the hearer through complaining about the pain and agony he feels because of the inconsideration from the side of Fanny towards his passion. The aim of Keats intends to make Fanny rethink and change some of her acts. This threatens the addressee's face and put pressure on how she would react in the future.

Another instance of hyperbole was realized in the positive politeness strategy of confession on which poses a threat to the speaker. This is seen in 13 instances accounting (12\%) of the total FTAs (109). They indicate the times Keats tried to persuade his beloved with his sincere love giving evidences showing his dedication. The following are examples where he exaggerates to the extent of not being able to live if she would not respond to his love:

(8) I am living today in yesterday: I was in a complete fascination all day. I feel myself at your mercy.

(9) I cannot exist without you - I am forgetful of everything but seeing you again - my Life seems to stop there - I see no further.

(10) My Love is selfish - I cannot breathe without you.

In all of the examples above, the threat is to the speaker's face as he exposes his desperation to the hearer through the use of emotive statements like "today in yesterday" or "My Love is selfish".

There are other positive FTAs with hyperbolic sense examined in the data which varied with variable percentages, namely: accusation and wishes (6\%), boasting (5.5\%), challenge (4\%), belittling, criticism, insults, contradiction and disagreements $(2.7 \%)$ respectively and finally disapproval $(2 \%)$. All of these strategies were threats to the hearer's face, i.e., Keats attempted to influence and change Fanny's attitude for his sake in different strategies, such as the following examples:

(11) If illness makes such an agreeable variety in the manner of your eyes I should wish you sometimes to be ill. I wish I had read your note before you went last night that I might have assured you how far I was from suspecting any coldness.

(12) You are to me an object intensely desirable - the air I breathe in a room empty of you is unhealthy. 


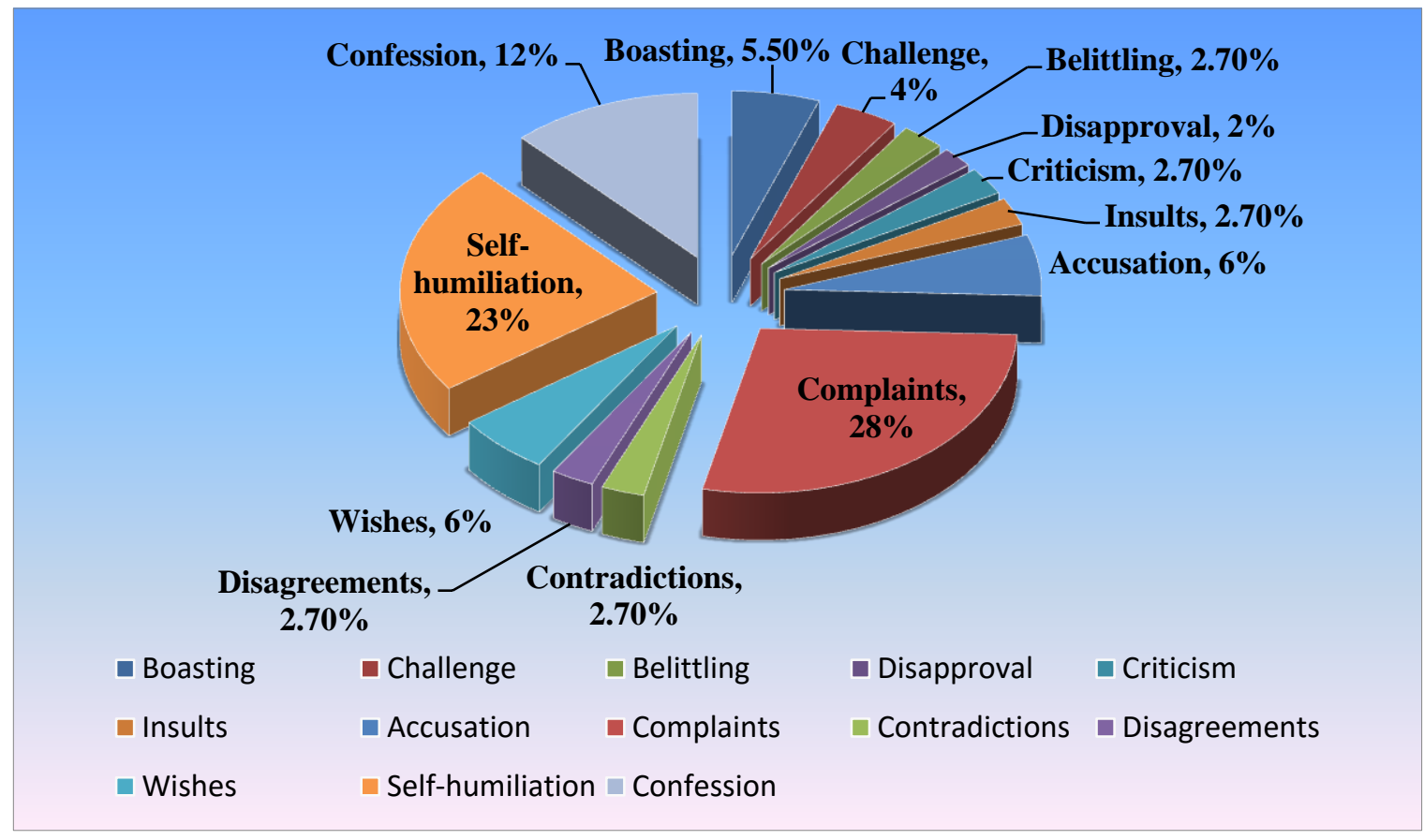

Figure 2. Positive Face Threatening Acts

Further analysis discovered that negative FTAs where less in occurrence than the positive ones. There were 58 instances of negative FTAs which posed a threat to the hearer's face whereas only 3 instances posed to the speaker's. Negative FTAs (Figure 3) are found in 13 different forms, 12 threatening the hearer and 1 threatening the speaker. The majority of negative FTAs are reflected in utterances of compliments representing (24.5\%) out of the total (61). An extensive hyperbolic language is used by Keats as he indulges in praising Fanny with variable characteristics by which he intends to put pressure on her to consider his aimed desire. Hence, the threat is posed on the addressee i.e., Fanny. Consider the following examples: what more pleasures than you have given so sweet a creature as you can give.

(14)I have no limit now to my love - You note came in just here - I cannot be happier away from you - 'T is richer than an Argosy of Pearles. Do not threat me even in jest. I have been astonished that Men could die Martyrs for religion - I have shudder'd at it -I shudder no more - I could be martyr'd for my Religion - Love is my religion - I could die for that - I could die for you.

(15) When you are in the room my thoughts never fly out of window: you always concentrate my whole senses.

In his complimenting statements, Keats tried to attract Fanny's attention to him by overflowing her with compliments and by how her beauty and attractiveness infatuated him such as when he considered her love as his own religion who could be a martyr for her sake.

The rest FTAs found in the data varied with a variable percentage distribution: admiration(15\%), anger $(11 \%)$, request and lust $(9.8 \%)$, warning $(6.5 \%)$, promise and 
reminding (5\%), offer (3.3\%)and suggestions, advice and threats ?(2\%) respectively out of the total (61). Each of which has a negative threat on the hearer's (Fanny) face to respond to and fulfill the speaker's (Keats) desire of a mutual love. Let's consider the following:

(16) Write me ever so few lines and tell you [for me] you will never forever be less kind to me than yesterday - You dazzled me.

(17) My dear Girl I love you ever and ever and without reserve. The more I have known you the more have I lov'd.

(18) There is nothing in the world so bright and delicate - When Brown came out with that seemingly true story against me last night, I felt it would be death to me if you had ever believed it - though agains anyone else I could muster up my obstinacy.

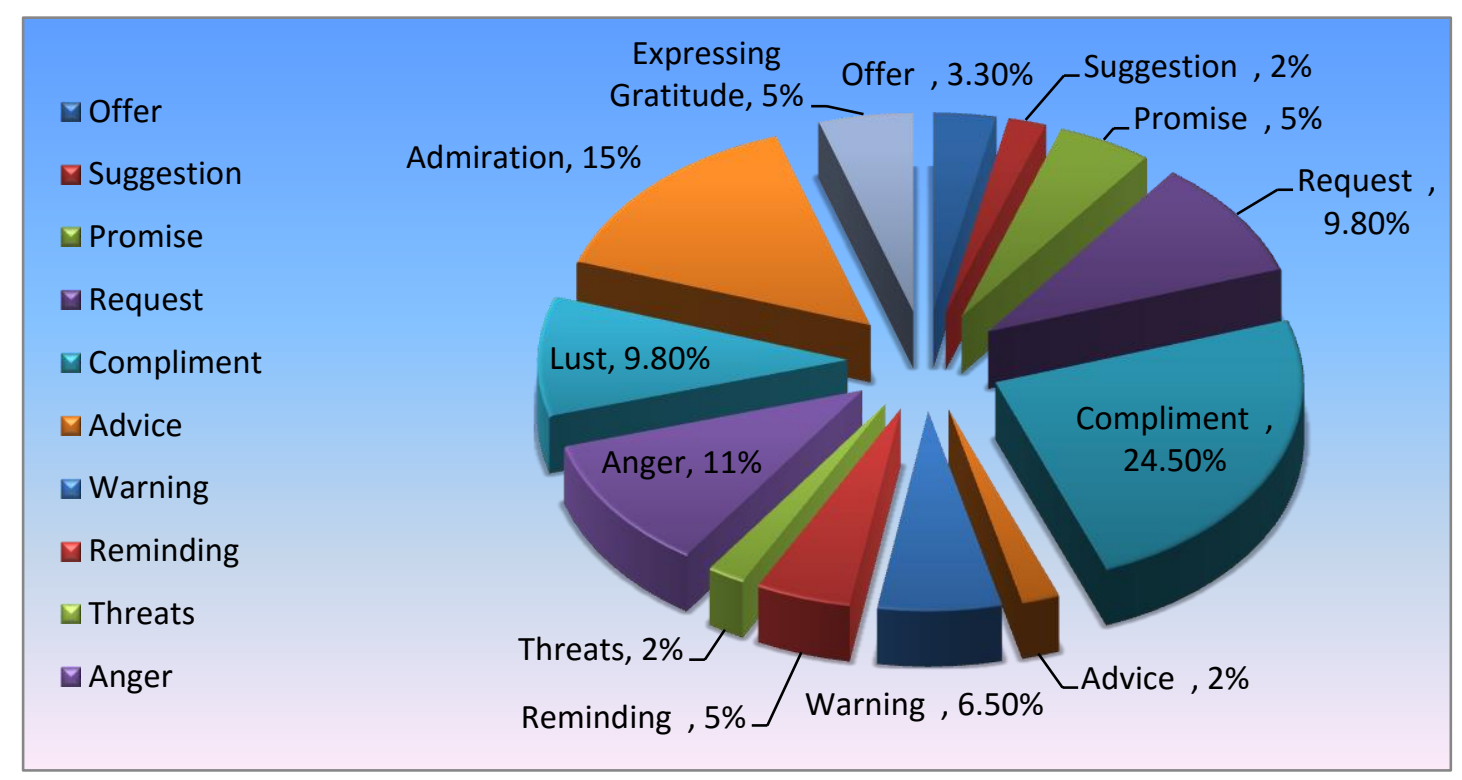

Figure 3. Negative Face Threatening Acts

\section{Findings and Conclusions}

This research investigates the figurative language "hyperbole" occurred in seven love letters written by John Keats to Fanny Brawne. It is based on the identification of hyperbole from a pragmatic perspective based on Brown and Levinson's Theory of Politeness (1987). The application of Brown and Levinson's discourse model to written language provides an interesting opportunity for the analysts in examining the writer's feelings, intentions and even the psychological status. The findings of the data analysis revealed that (170) FTAs were realized in Keats love letters where the positive politeness strategies carried the highest number of existence rather than the negative ones. Among the positive politeness strategies, which identify hyperbole, FTAs of "complaints" overwhelmed other FTAs found in the data. On the other hand, "compliments" as negative politeness strategies with hyperbolic function prevailed over other strategies in the data. 


\section{Macrothink}

Journal for the Study of English Linguistics

ISSN 2329-7034 2016, Vol. 4, No. 1

The findings reflected the core of politeness theory and proved its efficacy in analyzing the speaker's motivation of using hyperbolic language to express his emotional attitudes and self-appropriate image. The study also proved that within politeness, hyperbole has a strategic use, both as a means of a redressive means of positive politeness and a means to produce FTAs. Thus, in terms of the politeness theory framework, Keats attempted to redress FTAs and attended to Fanny's wants through hyperbolic intensification via different acts. This result evinced that hyperbole is trope that can be analyzed in terms of FTAs and love letters are examples of literary texts filled with hyperbolic expressions

\section{References}

Aristotle, \& Kennedy, G. A. (1991). On rhetoric: A theory of civic discourse. New York: Oxford University Press.

Brown, P., \& Levinson, S. (1987/2002). Politeness: Some Universal in Language Usage. Cambridge: Cambridge University Press.

Brooks, Cleanth, \& Robert Penn Warren, eds. (1938). Understanding Poetry. New York: Holt.

Burton, G. O. (1996-2003). "Silva Rhetoricae.” Brigham Young University. [Documento de internet disponible en rhetoric.byu.edu]

Cano Morn, 1. (2004). At the Risk of Exaggerating: How do Listeners React to Hyperbole? $\mathrm{http} /$ /anglogemanica

Cohn, Raymond. (1987). "The Problem of Intercultural Communication in Egyptian American Diplomatic Relations: International journal of Intercultural Relations II, 29-47. http://dx.doi.org/10.1093/applin/I.2.129

Claridge, Claudia. (2014). Hyperbole in English: A corpus- based study of exaggeration. Cambridge: Cambridge University Press.

Colston, H., \& Keller, S. (1998). "You'll Never Believe This: Irony and Hyperbole in Expressing Surprise". Journal of Psycholinguistic Research, 27(4). http://dx.doi.org/10.1093/applin/I.2.129

Colston, H., \& O'Brien, J. (2000). "Contrast and Pragmatics in Figurative Language. Anything Understatement Can Do, Irony Can Do Better". Elsevier Journal of Pragmatics, 32, 1557-1583. http://dx.doi.org/10.1016/S0378-2166(99)00110-1

Coulthard, M. (1985). An Introduction to Discourse Analysis. London: Longman.

Dascal, M., \& A. G. Gross. (1999). The Marriage of Pragmatics and Rhetoric. Philosophy and Rhetoric, 32(2). http://dx.doi.org/10.1353/par.1999.0001

Douglas, C. (1931). Overstatement in the New Testament. New York: Henry Holt and Company.

Fishman, A. (1991). Because this is who we are: Writing in the Amish community. In D. 
Barton, \& R. Ivanic (Eds.), Writing in the community (pp. 14-37). Newbury Park, CA: Sage. http://dx.doi.org/10.1093/applin/1.2.129

Gibbs, R. W. (1993). "Process and products in making sense of tropes". In Ortony, A. (ed.) Metaphor and Thought (2nd ed.). Cambridge: Cambridge University Press, 252-76. http://dx.doi.org/10.1017/CBO9781139173865.014

Gibbs, R. W. (1994a). The Poetics of Mind: Figurative Thought, Language and Understanding. Cambridge: Cambridge University Press.

Gibbs, R. (2000). Irony in talk among friends. Metaphor and Symbol 15(1 and 2), 5-27. http://dx.doi.org/10.1093/applin/I.2.129

Gibble, Patricia E. (2005). Eighteenth-Century Redware Folk Terms and Vessel Forms: A Survey of Utilitarian Wares from Southeastern Pennsylvania. Historical Archaeology, 39(2), 33-62. http://dx.doi.org/10.1093/applin/I.2.129

Gittings, Robert. (1987). Selected poems and letters of Keats. London: Heinemann.

Goffman, E. (1967) Interaction Ritual: Essays on Face to Face Behaviour. New York: Garden City.

Grice, H.P. (1975) "Logic and Conversation". In: Cole, P. and Morgan, J. (eds.) Syntax and Semantics Vol.III: Speech Acts. pp, 41-58. NewYork: Academic. http://dx.doi.org/10.1093/applin/I.2.129

Jaszczolts, K. (2002). Semantics and Pragmatics: Meaning in Language and Discourse. Delhi: Pearson Education.

Kallia, Alexandra. (2004). Linguistic politeness: the implicature approach. Multilingua, 23, 145-169. http://dx.doi.org/10.1515/mult.2004.003

Katriel, T. (1986) Brogezy: Ritual and Strategy in Israeli Children's Conflicts. Language in Society 14 (4): 467-90. http://dx.doi.org/10.1017/S0047404500011477

Kauffman, L. (1986). Discourses of Desire: Gender, Genre and Epistolary Fiction. London: Cornell University Press.

Kenyon, O. (1992). 800 Years of Women's Letters. Stroud: Sutton.

Kreuz, R. et.al (1996). Figurative Language Occurrences and Co-Occurrences in Contemporary Literature. Norwood, NJ: Ablex.

Leech, G. (1969). A Linguistic Guide to English Poetry. London: Longman Group Ltd.

Leech, G. (1983). Principles of Pragmatics. London and New York: Longman.

McCarthy, M., \& R. Carter. (2004). “There's millions of them": hyperbole in everyday $\begin{array}{lllll}\text { conversation. Journal of } & \text { Pragmatics, } & 36, & 149-184 .\end{array}$ http://dx.doi.org/10.1016/s03782166(03)00116-4

Mora, L. (2003). At the Risk of Exaggerating: How Do Listeners React to Hyperbole? 
Universitat De Valencia.

Moessner, L. (2001). Genre, Text Type, Style, Register: A Terminological Maze? European Journal of English Studies, 5(2) 131-138. http://dx.doi.org/10.1076/ejes.5.2.131.7312

Norrick, N. R. (1982). "On the semantics of overstatement". In Detering, K. et al. (eds.) Akten des 16 Linguistischen Kolloquiums Kiel, 1981, Band II: Sprache erkennen und verstehen. Tübingen: Niemeyer, 168-76. http://dx.doi.org/10.1515/9783111612294.168

Norrick, N. (2004). Hyperbole, extreme case formulations. Journal of Pragmatics, 36, 1727-1739. http://dx.doi.org/10.1016/j.pragma.2004.06.006

The Oxford English Dictionary. $2^{\text {nd }}$ ed. (1989) Oxford Clarendon Press.

Perrine, L. (1969). Sound and Sense. New York: Harcourt, Brace \&World Inc.

Roberts, R. M., \& Kreuz, R. J. (1994). Why do people use figurative language? Psychological Science, 5, 159-163. http://dx.doi.org/10.1111/j.1467-9280.1994.tb00653.x

Scollon, and Scollon. (1995). Narrative, Literacy and Face in Interethnic Communication. New Jersey: Ablex Publishing Cop.

Spitzbardt, H. (1963) "Overstatement and Understatement in British and American English". Philologica Pragensia, 6, 45. 277-286. http://dx.doi.org/10.1093/applin/1.2.129

Terkourafi, Marina. (2003). Generalised and particularised implicatures of linguistic politeness. In: Kuhnlein, Peter, Rieser, Hannes, Zeevat, Henk (Eds.), Perspectives on Dialogue in the New Millennium. John Benjamins, Amsterdam, pp. 149-164 http://dx.doi.org/10.1075/pbns.114.09ter

Thomas, J. (1997). Meaning in Interaction: an Introduction to pragmatics. London: Longman Group Ltd.

Thornborrow, J., \& Wareing, S. (1998). Patterns in Language: An Introduction to Language and Literary Style. London: Routledge.

White, R. S. (2010). John Keats A Literary Life. London: Palgrave Macmillan.

Yaqubi, M., Davoudi Sharifabad, E., \& Abdul Rahman, W. R. E (2012). Gender-linked Choice of Politeness Strategies Applied to Translation of Persian Face-threatening Acts into English. International Journal of Applied Linguistics \& English Literature (Special Issue). 1(7). pp 66-80. Ebscohost Publication: Australia. ISSN 2200-3592 (Print), ISSN 2200-3452 (Online) Available online at: http://www.ijalel.org/viewpdf.aspx ?articleid=179

Yaqubi, M. (2016). Conversational Maxim View of Politeness: Focus on Politeness Implicatures raised in Performing Persian Offers and Invitations. Theory and Practice in Language Studies, 6(1), pp. 52-58. http://dx.doi.org/10.17507/tpls.0601.07

Yule, G. (1997). Pragmatics. Oxford: Oxford University Press. http://englishhistory.net/keats/letters/love-letter-to-fanny-brawne-13-october-1819/ 


\section{Copyright Disclaimer}

Copyright for this article is retained by the author(s), with first publication rights granted to the journal.

This is an open-access article distributed under the terms and conditions of the Creative Commons Attribution license (http://creativecommons.org/licenses/by/3.0/). 